\title{
EMPIRICAL MODELS FOR PERFORMANCE OF DRIPPERS APPLYING CASHEW NUT PROCESSING WASTEWATER ${ }^{1}$
}

\author{
KETSON BRUNO DA SILVA²; RAFAEL OLIVEIRA BATISTA ${ }^{2 *}$; FRANCISCO DE OLIVEIRA MESQUITA ${ }^{2}$; \\ DANIELA DA COSTA LEITE COELHO ${ }^{2}$; WESLEY DE OLIVEIRA SANTOS ${ }^{2}$
}

\begin{abstract}
The objective of this work was to develop empirical models for hydraulic performance of drippers operating with cashew nut processing wastewater depending on operating time, operating pressure and effluent quality. The experiment consisted of two factors, types of drippers $\left(\mathrm{D} 1=1.65 \mathrm{~L} \mathrm{~h}^{-1}, \mathrm{D} 2=2.00 \mathrm{~L} \mathrm{~h}^{-1}\right.$ and D3 $\left.=4.00 \mathrm{~L} \mathrm{~h}^{-1}\right)$, and operating pressures $(70,140,210$ and $280 \mathrm{kPa})$, with three replications. The flow variation coefficient (FVC), distribution uniformity coefficient (DUC) and the physicochemical and biological characteristics of the effluent were evaluated every 20 hours until complete 160 hours of operation. Data were interpreted through simple and multiple linear stepwise regression models. The regression models that fitted to the FVC and DUC as a function of operating time were square root, linear and quadratic, with $17 \%, 17 \%$ and $8 \%$, and $17 \%, 17 \%$ and $0 \%$, respectively. The regression models that fitted to the FVC and DUC as a function of operating pressures were square root, linear and quadratic, with $11 \%, 22 \%$ and $0 \%$ and the $0 \%, 22 \%$ and $11 \%$, respectively. Multiple linear regressions showed that the dissolved solids content is the main wastewater characteristic that interfere in the FVC and DUC values of the drip units D1 (1.65 L h-1) and D3 (4.00 L h-1), operating at work pressure of $70 \mathrm{kPa}(\mathrm{P} 1)$.
\end{abstract}

Keywords: Effluent. Emitters. Operating pressure. Flow variation coefficient. Distribution uniformity coefficient.

\section{MODELOS EMPÍRICOS DO DESEMPENHO DE GOTEJADORES APLICANDO ÁGUA RESIDUÁRIA DA CASTANHA DE CAJU}

RESUMO - Este trabalho objetivou obter modelos empíricos do desempenho hidráulico de gotejadores operando com água residuária da castanha de caju em função do tempo de operação, da pressão de serviço e da qualidade do efluente. O experimento foi montado com dois fatores: três tipos de gotejadores (D1 - 1,65 L h $\mathrm{h}^{-1}$; D2 - 2,00 L h${ }^{-1}$ e D3 - 4,00 L h$\left.{ }^{-1}\right)$ e quatro pressões de serviço $(70,140,210$ e $280 \mathrm{kPa})$, com três repetições. Avaliaram-se a cada $20 \mathrm{~h}$ os valores dos coeficientes de variação de vazão (FVC) e da uniformidade de distribuição (DUC), além das características físico-químicas e biológicas do efluente até completar o tempo de operação de 160 h. Os dados foram interpretados por meio das análises de regressão simples e linear múltipla stepwise. Para os dados de FVC e DUC em função do tempo de operação, 17, 17 e 8\% e 17, 17 e $0 \%$ dos modelos de regressão ajustados foram o raiz quadrada, o linear e o quadrático, respectivamente. Na relação de FVC e DUC com pressões de serviço, 11, 22 e $0 \%$ e 0,22 e 11\% dos modelos de regressão ajustados foram o raiz quadrada, o linear e o quadrático, respectivamente. As regressões lineares múltiplas mostraram que o teor de sólidos dissolvidos foi a característica da água residuária que mais interferiu nos valores de FVC e DUC das unidades gotejadoras D1e D3 operando na pressão de serviço de $70 \mathrm{kPa}$.

Palavras-chave: Efluente. Emissores. Pressão de serviço. Coeficientes de variação da vazão e de uniformidade de distribuição.

\footnotetext{
*Corresponding author

${ }^{1}$ Received for publication in $07 / 29 / 2014$; accepted in 02/16/2016. Paper extracted from the masters dissertation of the first author.

${ }^{2}$ Department of Environmental and Technological Sciences, Universidade Federal Rural do Semi-Árido, Mossoró, RN, Brazil; ketsonbruno@hotmail.com,_rafaelbatista@ufersa.edu.br, mesquitaagro@yahoo.com.br, danielacleite@yahoo.com.br,
} wesley_ufersa@yahoo.com.br. 


\section{INTRODUCTION}

The cashew (Anacardium occidentale L.) is one of the most important fruit species cultivated in tropical regions, with an area of 586,237 ha in Brazil. Its main economic products are the edible kernel and liquid from the nutshell (Conab, 2015). The Brazilian Northeast region accounts for $98 \%$ of national production of cashew nuts, with the largest plantations located mainly in coastal and transition bands in the states of Ceara and Rio Grande do Norte (CONAB, 2015).

The cashew nut processing generates a waste that is hazardous for the environment. The processing steps such as pressing, storage, drying, classification, washing, extraction of cashew nut liquid and shelling produce potentially polluting effluents (LOPES et al., 2011).

According to Souza et al. (2015), the use of wastewater in agriculture has benefits, such as the increased availability of water for urban and industrial sectors, and nutrient and organic matter contribution to agricultural crops.

Wastewater application with drip irrigation systems has the advantage of protect surface and ground water sources and improvement of public health due to the adsorption of contaminants in the clay exchange complex, nutrient uptake by plants and minimization of pathogens (ROWAN; MANCL; TUOVINEN, 2013).

The clogging of drippers is the major concern in drip irrigation systems that apply wastewater, because its high levels of suspended solids, organic matter and nutrients (YAN et al., 2010). Previous studies have reported causes for clogging of drippers operating with wastewater (BATISTA et al., 2014; FERNANDES et al., 2014; KATZ et al., 2014; MESQUITA et al., 2015), identifying the physical agents in the suspended solids; chemical agents from precipitation reactions; and organic agents because the growth and metabolism of microorganisms, forming biofilms.

Several studies reported a compromised hydraulic performance of drip irrigation systems operating with different types of wastewater, due to partial or total clogging of drippers (PUIGBARGUES et al., 2010; BATISTA et al., 2011; BATISTA et al., 2013).

Empirical models relating hydraulic performance of drip irrigation systems with the variables operating time (BATISTA et al., 2013), wastewater quality (BATISTA et al., 2011) and intrinsic characteristics of drippers (BATISTA et al., 2012; OLIVER et al., 2014) assists in choosing the technic and the time of use preventive and corrective measures regarding dripper obstructions when applying wastewater.

Therefore, the objective of this work was to develop empirical models of hydraulic performance of drippers operating with cashew nut processing wastewater, related to the variables operating time, operating pressure and effluent quality.

\section{MATERIAL AND METHODS}

The experiment was conducted from March 11 to April 20, 2012, at the Water Reuse Experimental Unit (UERA), Federal Rural University of Semi-Arid (UFERSA) in Mossoro, $\mathrm{RN}$, Brazil $\left(5^{\circ} 12^{\prime} 27^{\prime \prime} \mathrm{S}\right.$ and $\left.37^{\circ} 19^{\prime} 21^{\prime \prime} \mathrm{W}\right)$. According to the Köppen classification, the climate is BSwh, semiarid, hot, with rainy season in the summer (ALVARES et al., 2013).

A $2.0 \mathrm{~m}$ wide, $8.0 \mathrm{~m}$ long experimental bench was built in the UERA, which had waterproof floor with slope of $1 \%$ and a channel of $2 \%$ slope to recirculate the effluent, in order to minimize losses by evaporation. A $5.0 \mathrm{~m}^{3}$ reservoir was built next to the experimental bench for storage of cashew nut processing wastewater. The experimental bench was equipped with four drip irrigation units with a $1.0 \mathrm{hp}$ pump, a $1.5 \mathrm{~m}^{3} \mathrm{~h}^{-1}$ hydrometer, a $130 \mu \mathrm{m}$ screen filter, four PVC manifolds of $32 \mathrm{~mm}$, four pressure regulators units with gate valves and analog manometers with glycerin and 36 polyethylene lateral lines of $16 \mathrm{~mm}$ diameter and $1.8 \mathrm{~mm}$ thick, with nine lateral lines per irrigation unit (Figure 1).

The experiment consisted of two factors, the types of drippers (D1, D2 and D3) and operating pressures $(70,140,210$ and $280 \mathrm{kPa})$, with three replications.

Each manifold had a gate valve for controlling the operating pressure of the drip units. The evaluated pressures were 70 (P1), 140 (P2), 210 (P3) and $280 \mathrm{kPa}$ (P4). Moreover, each manifold of the drip units had nine connectors with sealing rubber, for inserting the nine lateral lines of $8.0 \mathrm{~m}$ in length, three for each one of the evaluated dripper type. The characteristics of the evaluated dripper are presented in Table 1 and their images in Figure 2. 


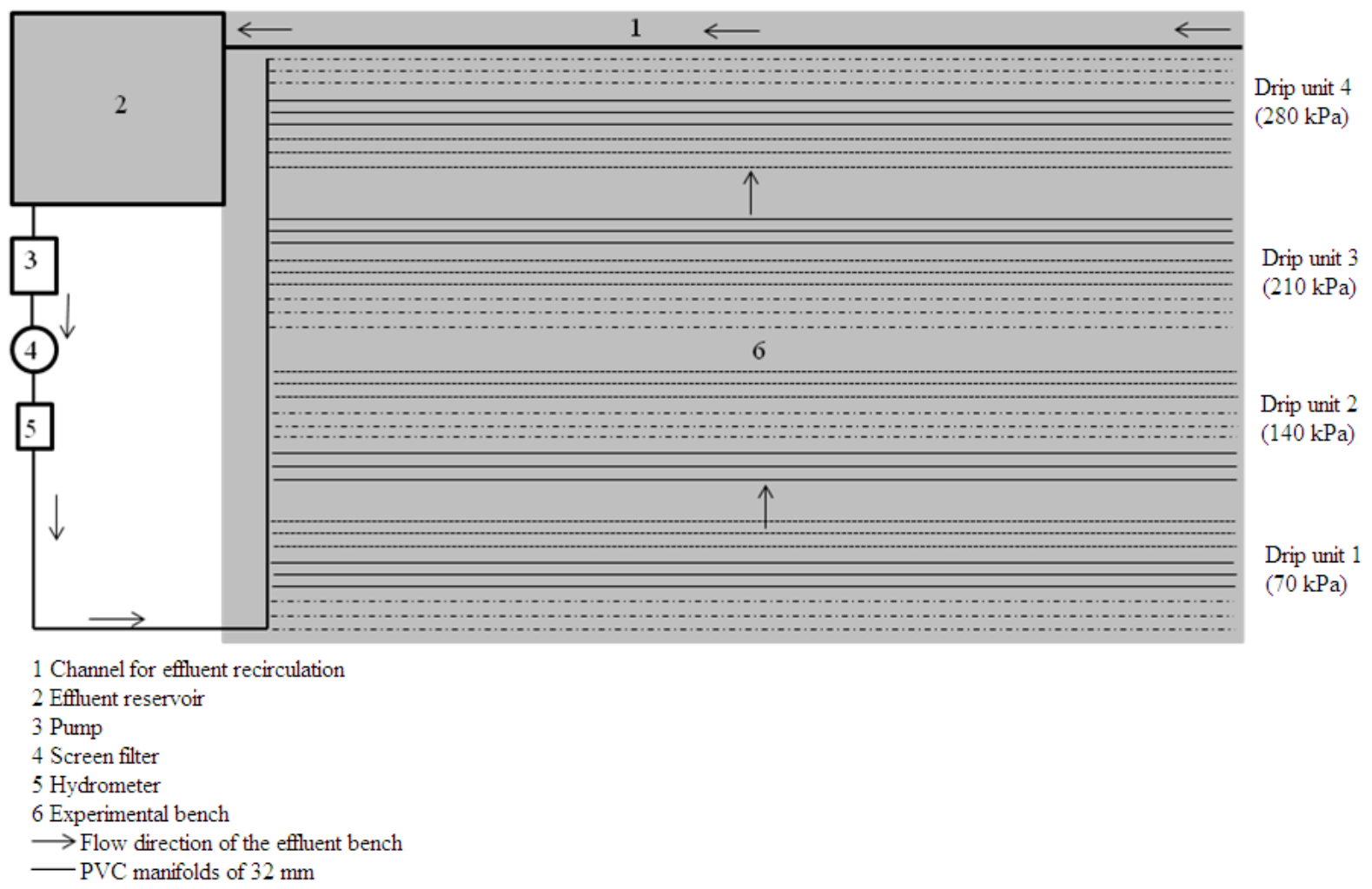

Figure 1. Scheme of the experimental bench built at the Water Reuse Experimental Unit (UERA), showing the four drip units operating at the predetermined pressures.

Table 1. Drippers (D) used in the experiments and their characteristics regarding pressure compensating device (PCD), the nominal flow $(\mathrm{Q})$, flow coefficient $(\mathrm{k})$, exponent of the flow which characterizes the flow regime (x), filtering area (A), labyrinth length $(\mathrm{L})$, manufacturing coefficient of variation $\left(\mathrm{CV}_{\mathrm{m}}\right)$, recommended pressure range $(\mathrm{P})$ and spacing between emitters (SE)

\begin{tabular}{cccccccccc}
\hline $\mathbf{D}$ & $\mathbf{P C D}^{*}$ & $\begin{array}{c}\mathbf{Q}^{*} \\
\left(\mathbf{L ~ h} \mathbf{~}^{-1}\right)\end{array}$ & $\mathbf{k}^{*}$ & $\mathbf{x}^{*}$ & $\begin{array}{c}\mathbf{A} \\
\left(\mathbf{m m}^{\mathbf{2}}\right)\end{array}$ & $\begin{array}{c}\mathbf{L} \\
(\mathbf{m m})\end{array}$ & $\begin{array}{c}\mathbf{C V}_{\mathbf{m}}{ }^{*} \\
(\mathbf{\%})\end{array}$ & $\begin{array}{c}\mathbf{P}^{*} \\
(\mathbf{k P a})\end{array}$ & $\begin{array}{c}\mathbf{S E}^{*} \\
(\mathbf{m})\end{array}$ \\
\hline D1 & No & 1,65 & 0,53 & 0,48 & $4,0^{* *}$ & $37^{* *}$ & $\leq 5$ & $60-150$ & 0,30 \\
D2 & Yes & 2,00 & 2,00 & 0,00 & $2,0^{*}$ & $35^{*}$ & $\leq 7$ & $50-400$ & 1,00 \\
D3 & Yes & 4,00 & 4,00 & 0,00 & $2,9^{*}$ & $35^{*}$ & $\leq 7$ & $50-400$ & 1,00 \\
\hline
\end{tabular}

*Information from manufacturer's catalogs; ** information measured with a digital caliper ruler (accuracy of $0.01 \mathrm{~mm}$ ). CNJ - anti-draining system.

A

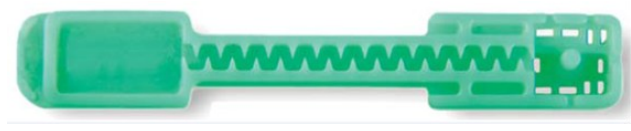

B

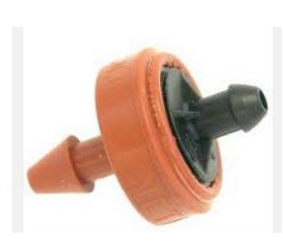

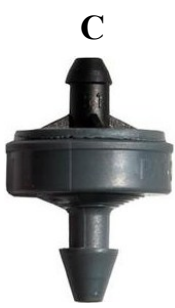

Figure 2. Types of drippers $(\mathrm{D} 1=\mathrm{A}, \mathrm{D} 2=\mathrm{B}$ and $\mathrm{D} 3=\mathrm{C})$ used for application of cashew nut processing wastewater.

The cashew nut processing wastewater used in the present work was from a wastewater treatment plant (WWTP) of a cashew industry, located in Mossoro, RN, Brazil. The collection was performed in the sedimentation tank of the WWTP. The reservoir of $5.0 \mathrm{~m}^{3}$ of the experimental bench was supplied weekly with $1.0 \mathrm{~m}^{3}$ of this effluent, compensating the water losses.
Seven equidistant emitters were identified in all 36 lateral lines, with white paint, in order to evaluated the hydraulic performance of the drip units. The flow of each dripper was found by the gravimetric method, collecting the effluent volume in a three-minute period, following the recommendations of ABNT (2006), using the Equation 1, 


$$
\mathrm{Q}=\frac{\mathrm{V}}{1000 \cdot \mathrm{t}} \cdot 60
$$

were $\mathrm{Q}=$ dripper flow $\left(\mathrm{L} \mathrm{h}^{-1}\right), \mathrm{V}=$ effluent volume collected $(\mathrm{mL})$; and $\mathrm{t}=$ effluent collection time (min).

The hydraulic performance indicators used to detect dripper obstruction levels were the distribution uniformity coefficient (DUC) (Equations 2) and flow variation coefficient (FVC), (Equations 3),

$$
\begin{aligned}
& F C V=100 \cdot \frac{\sqrt{\frac{\sum_{i=1}^{n}\left(q_{i}-\bar{q}\right)^{2}}{n_{e}-1}}}{\bar{q}} \\
& D U C=100 \cdot \frac{q_{25 \%}}{\bar{q}}
\end{aligned}
$$

where $\mathrm{FVC}=$ flow variation coefficient (\%); DUC = distribution uniformity coefficient (\%); $\mathrm{q}=$ average flow of drippers $\left(\mathrm{L} \mathrm{h}^{-1}\right) ; \mathrm{q}_{\mathrm{i}}=$ flow rate of each dripper $\left(\mathrm{L} \mathrm{h}^{-1}\right) ; \mathrm{n}_{\mathrm{e}}=$ number of evaluated drippers; and $\mathrm{q}_{25 \%}=$ average of the $25 \%$ lower values of flow of the drippers $\left(\mathrm{L} \mathrm{h}^{-1}\right)$.

These indicators were evaluated every 20 hours of operation of the drip units, starting at zero and ending at 160 hours of operation.

According to the recommendations of Batista et al. (2013), the drip units work an average of four hours a day until completing $160 \mathrm{~h}$.

The operating pressures $\mathrm{P} 1(70 \mathrm{kPa}), \mathrm{P} 2(140$ $\mathrm{kPa}), \quad \mathrm{P} 3(210 \mathrm{kPa})$ and P4 (280 $\mathrm{kPa})$ were maintained in the four evaluated irrigation units, using simultaneously gate valves and analog gauges $(0-400 \mathrm{kPa})$. The initial operating time $(0 \mathrm{~h})$, when there was no obstruction, presented flow variations between drippers around 7\%, as proposed by the ISO 9261 (ABNT, 2006).

The physicochemical and biological characteristics of the cashew nut processing wastewater was assessed following the recommendations of the standard methods for the examination of water and wastewater (RICE; BAIRD; CLESCERI, 2012). Therefore, composite samples were obtained from single samples and analyzed by different laboratories. Table 2 presents the physicochemical and biological characteristics of the cashew nut processing wastewater used in this work.

\begin{tabular}{|c|c|c|c|c|c|c|c|c|c|c|}
\hline \multirow{2}{*}{ Characteristics } & \multicolumn{10}{|c|}{ Operating periods (hour) } \\
\hline & $\mathbf{0}$ & 20 & 40 & 60 & 80 & 100 & 120 & 140 & 160 & Average \\
\hline $\mathrm{pH}$ & 8,45 & 8,50 & 7,57 & 7,00 & 7,19 & 7,32 & 7,66 & 7,71 & 7,07 & 7,61 \\
\hline $\mathrm{Ca}^{2+}\left(\mathrm{mmol}_{\mathrm{c}} \mathrm{L}^{-1}\right)$ & 9,47 & 12,32 & 15,08 & 9,17 & 9,00 & 12,90 & 12,62 & 11,47 & 14,95 & 11,89 \\
\hline $\mathrm{Mg}^{2+}\left(\mathrm{mmol}_{\mathrm{c}} \mathrm{L}^{-1}\right)$ & 3,58 & 3,52 & 3,91 & 3,85 & 4,02 & 4,30 & 3,76 & 3,40 & 8,50 & 4,32 \\
\hline $\mathrm{Cl}^{-}\left(\mathrm{mmolc} \mathrm{L}^{-1}\right)$ & 22,87 & 24,93 & 20,00 & 19,00 & 22,13 & 25,00 & 30,00 & 26,33 & 20,67 & 23,44 \\
\hline $\mathrm{CO}_{3}{ }^{2-}\left(\mathrm{mmol}_{\mathrm{c}} \mathrm{L}^{-1}\right)$ & 0,00 & 0,00 & 0,00 & 0,00 & 0,00 & 0,00 & 0,00 & 0,00 & 0,00 & 0,00 \\
\hline $\mathrm{HCO}_{3}^{-}\left(\mathrm{mmol}_{\mathrm{c}} \mathrm{L}^{-1}\right)$ & 6,73 & 6,70 & 6,20 & 4,87 & 4,83 & 4,87 & 4,87 & 5,00 & 8,00 & 5,79 \\
\hline $\operatorname{Mn}\left(\mathrm{mg} \mathrm{L}^{-1}\right)$ & 0,33 & 0,31 & 0,34 & 0,34 & 0,32 & 0,24 & 0,24 & 0,30 & 0,30 & 0,3 \\
\hline $\mathrm{Fe}\left(\mathrm{mg} \mathrm{L}^{-1}\right)$ & 0,47 & 0,52 & 0,46 & 0,35 & 0,48 & 0,53 & 0,53 & 0,52 & 0,43 & 0,48 \\
\hline $\mathrm{SS}\left(\mathrm{mg} \mathrm{L}^{-1}\right)$ & 103 & 170 & 234 & 286 & 333 & 370 & 355 & 377 & 386 & 291 \\
\hline $\mathrm{DS}\left(\mathrm{mg} \mathrm{L}^{-1}\right)$ & 2113 & 2230 & 2340 & 2360 & 2371 & 2389 & 2408 & 2401 & 2487 & 2344 \\
\hline TC (MPN $100 \mathrm{~mL}^{-1}$ ) & 4 & 495 & 35 & 97 & 58 & 50 & 50 & 545 & 34 & 153 \\
\hline
\end{tabular}

Table 2. Physicochemical and biological characteristics of the cashew nut processing wastewater used in the operating periods of the drip irrigation units.

DS = dissolved solids; $\mathrm{SS}=$ suspended solids, $\mathrm{TC}=$ total coliforms; and MPN $=$ most probable number

The effluent $\mathrm{pH}$ was evaluated at the laboratory of soil, water and plant analysis (LASAP) of the Department of Environmental Sciences and Technology of the UFERSA. The iron $(\mathrm{Fe})$ and manganese $(\mathrm{Mn})$ concentrations were evaluated by atomic absorption spectrophotometry; the carbonate $\left(\mathrm{CO}_{3}{ }^{2-}\right)$, bicarbonate $\left(\mathrm{HCO}_{3}^{-}\right)$, calcium $\left(\mathrm{Ca}^{2+}\right)$, chloride $\left(\mathrm{Cl}^{-}\right)$and magnesium $\left(\mathrm{Mg}^{2+}\right)$ concentrations by the titrimetric method; the suspended solids (SS) and total solids (TS) concentrations by the gravimetric method; and the dissolved solids (DS) concentration by the difference between TS and SS.

The total coliform (TC) population were evaluated in the animal products inspection laboratory of the Animal Sciences Department of the UFERSA, using the multiple tube method.

Simple and multiple linear stepwise regression models were chosen based on the significance of the regression coefficients, by applying the t-test at significance level of $10 \%$ to the coefficient of determination $(\geq 60 \%)$ and the process 
at study. The computer program System for Statistical Analysis 9.1 (SAEG, 2007) was used for the statistical analyzes of the data.

\section{RESULTS AND DISCUSSION}

The application of cashew nut processing wastewater, even with physicochemical treatment, caused obstructions of drippers with biofilm. Similar results were found by Dazhuang et al. (2009), Yan et al. (2010), Oliver, Hewa and Pezzaniti (2014), Fernandes et al. (2014) and Mesquita et al. (2015) with drip units applying different wastewaters. However, obstruction levels were more pronounced in drip units operating at pressure of $70 \mathrm{kPa}$, which had lower effluent flow rate in the drips compared with the other pressures, favoring the biofilm formation. Similar result was found by Yavuz et al. (2010) with irrigation at field conditions after three years of application of water with chemical clogging agents, in which the drippers subjected to lower operating pressures, 40 to $70 \mathrm{kPa}$, were the most susceptible to clogging.

The combinations D1xP1, D2xP1, D3xP1, $\mathrm{D} 1 \times \mathrm{P} 2$ and $\mathrm{D} 3 \times \mathrm{P} 3$ presented significant changes in FVC values depending on the operating time of drip units (Table 3). The linear regression model best fitted to the combinations D1xP1 and D3xP1. The square root regression model best fitted to the combinations $\mathrm{D} 2 \times \mathrm{P} 1$ and $\mathrm{D} 1 \times \mathrm{P} 2$. The quadratic model best fitted to the combination $\mathrm{D} 3 \mathrm{xP} 3$, and the maximum value of FVC $(5.11 \%)$ was found at $85 \mathrm{~h}$ of operating time, applying the first derivative to the model. The other combinations presented no effect in the performance of drippers, with the mean being their best representation.

After 160 hours of operation of drip units, the lowest $(3.427 \%)$ and the highest $(33.525 \%)$ FVC values were found in the combinations $\mathrm{D} 3 \mathrm{xP} 4$ and D1xP1, respectively.

Table 3. Regression equations fitted to the average values of the FVC depending on the operating times (T; hour) of drip units for the combinations of types of drippers and operating pressures $(\mathrm{P} ; \mathrm{kPa})$.

\begin{tabular}{clc}
\hline Combinations & \multicolumn{1}{c}{ Regression equations } & $\mathbf{R}^{2}$ \\
\hline D1 x P1 & $F \hat{V} C=7,925+0,160^{* *} T$ & 0,69 \\
D2 x P1 & $F \hat{V C}=3,643+0,838^{* *} T^{0,5}-0,0453^{* * *} T$ & 0,81 \\
D3 x P1 & $F \hat{V} C=3,035+0,0324^{* *} T$ & 0,93 \\
D1 x P2 & $F \hat{V C}=3,114+1,303^{* *} T^{0,5}-0,0990^{* *} T$ & 0,80 \\
D2 x P2 & $F \hat{V} C=F \bar{V} C=4,516$ & - \\
D3 x P2 & $F \hat{V C}=F \bar{V} C=4,113$ & - \\
D1 x P3 & $F \hat{V} C=F \bar{V} C=6,963$ & - \\
D2 x P3 & $F \hat{V C}=F \bar{V} C=5,672$ & - \\
D3 x P3 & $F \hat{V} C=3,376+0,0409^{* *} T-0,000241^{*} T^{2}$ & - \\
D1 x P4 & $F \hat{V C}=F \bar{V} C=5,122$ \\
D2 x P4 & $F \hat{V} C=F \bar{V} C=4,611$ & - \\
D3 x P4 & $F \hat{V C}=F \bar{V} C=3,427$ & - \\
\hline
\end{tabular}

** and * significant at 1 and $5 \%$ probability by the "t" test.

Batista et al. (2014) also obtained 12 combinations of FVC as a function of four operating times for drip units with three types of drippers, supplied with swine wastewater and public water. These authors reported that the square root, quadratic and linear regression models fitted 58, 17 and $8 \%$ of the combinations, respectively, differing from the results found in the present study $(17,17$ and $8 \%$, respectively).

The operating time affected the DUC values, indicating an obstruction process in the drippers
(Table 4). The linear regression model best fitted to the combinations D1xP1 and D $3 \times P 1$. The square root regression model best fitted to the combinations $\mathrm{D} 2 \mathrm{xP} 1$ and D1xP2. The mean was the best representation for the other combinations, indicating greater resistance to clogging.

After 160 hours of operation of drip units, the lowest and the highest value of DUC were 61.365 and $96.518 \%$ for combinations $\mathrm{D} 1 \times \mathrm{P} 1$ and $\mathrm{D} 3 \times \mathrm{P} 4$, respectively. 
Table 4. Regression equations fitted to the average values of the DUC depending on the operating times (T; hours) of drip units for combinations of types of drippers and operating pressures $(\mathrm{P} ; \mathrm{kPa})$.

\begin{tabular}{clc}
\hline Combination & \multicolumn{1}{c}{ Regression equations } & $\mathbf{R}^{2}$ \\
\hline D1 x P1 & $D \hat{U} C=95.285-0.212^{* *} T$ & 0,76 \\
D2 x P1 & $D \hat{U} C=96,470-1,157^{* *} T^{0,5}+0,0620^{*} T$ & 0,79 \\
D3 x P1 & $D \hat{U} C=96,709-0,0389^{* *} T$ & 0,85 \\
D1 x P2 & $D \hat{U} C=96,914-1,590^{* * *} T^{0,5}+0,121^{* *} T$ & 0,75 \\
D2 x P2 & $D \hat{U} C=D \bar{U} C=95,034$ & - \\
D3 x P2 & $D \hat{U} C=D \bar{U} C=95,694$ & - \\
D1 x P3 & $D \hat{U} C=D \bar{U} C=91,601$ & - \\
D2 x P3 & $D \hat{U} C=D \bar{U} C=93,928$ & - \\
D3 x P3 & $D \hat{U} C=D \bar{U} C=95,006$ & - \\
D1 x P4 & $D \hat{U} C=D \bar{U} C=94,298$ & - \\
D2 x P4 & $D \hat{U} C=D \bar{U} C=94,994$ & - \\
D3 x P4 & $D \hat{U} C=D \bar{U} C=96,518$ &
\end{tabular}

** and * significant at 1 and $5 \%$ probability by the "t" test.

Batista et al. (2011) reported that the quadratic and linear regression models best fitted to the DUC data and to the operating time with drip units operating with secondary and tertiary domestic wastewater, respectively. Batista et al. (2013) reported that the quadratic regression model best fitted to the DUC data and to the operation time with drip units operated daily with public water for $2 \mathrm{~h}$ followed by another $2 \mathrm{~h}$ with swine wastewater, for $160 \mathrm{~h}$.

The operating pressure affected the FVC values for the combinations $\mathrm{D}_{1 \times T_{20} \mathrm{~h}} \mathrm{D} 2 \mathrm{xT}_{20 \mathrm{~h}}$,
$\mathrm{D}_{1 \times T_{60 h}}, \mathrm{D}_{3 \times T_{60}}, \quad \mathrm{D}_{1 \times T_{80}}, \quad \mathrm{D} 2 \mathrm{xT}_{80 \mathrm{~h}}, \quad \mathrm{D} 1 \mathrm{xT}_{100 \mathrm{~h}}$, $\mathrm{D} \mathrm{xT}_{160 \mathrm{~h}}$ and $\mathrm{D} 3 \mathrm{xT}_{160 \mathrm{~h}}$ (Table 5). The square root regression model best fitted to the combination $\mathrm{D} 1 \mathrm{xT}_{20 \mathrm{~h}}$. The linear regression model best fitted to the combinations $\mathrm{D} 2 \mathrm{xT}_{20 \mathrm{~h}}, \mathrm{D} 1 \mathrm{xT}_{60 \mathrm{~h}}, \quad \mathrm{D} 1 \mathrm{xT}_{80 \mathrm{~h}}$, $\mathrm{D} 1 \mathrm{xT}_{100 \mathrm{~h}}, \mathrm{D} 1 \mathrm{xT}_{160 \mathrm{~h}}$ and $\mathrm{D} 3 \mathrm{xT}_{160 \mathrm{~h}}$. The quadratic regression model best fitted to the combinations $\mathrm{D} \mathrm{xT}_{60 \mathrm{~h}}$ and $\mathrm{D} 2 \mathrm{xT}_{80 \mathrm{~h}}$. The mean was the best representation of the FVC values and operating pressures for the other combinations.

Table 5. Regression equations fitted to the average values of the FVC depending on the operating pressure $(\mathrm{P} ; \mathrm{kPa})$ of drip units for combinations of types of drippers and operating times ( $T$; hours).

\begin{tabular}{|c|c|c|}
\hline Combinations & Regression equations & $\mathbf{R}^{2}$ \\
\hline $\mathrm{D} 1 \times \mathrm{T}_{0 \mathrm{~h}}$ & $F \hat{V} C=F \bar{V} C=4,598$ & - \\
\hline $\mathrm{D} 2 \times \mathrm{T}_{0 \mathrm{~h}}$ & $F \hat{V} C=F \bar{V} C=4,073$ & - \\
\hline $\mathrm{D} 3 \times \mathrm{T}_{0 \mathrm{~h}}$ & & - \\
\hline $\mathrm{D} 1 \times \mathrm{T}_{20 \mathrm{~h}}$ & $F \hat{V C}=50,952-5,931^{* *} P^{0,5}+0,193^{* *} P$ & 0,99 \\
\hline $\mathrm{D} 2 \times \mathrm{T}_{20 \mathrm{~h}}$ & $F \hat{V C}=6,668-0,0109^{\circ} P$ & 0,72 \\
\hline $\mathrm{D} 3 \times \mathrm{T}_{20 \mathrm{~h}}$ & $F \hat{V} C=F \bar{V} C=3,632$ & - \\
\hline $\mathrm{D} 1 \times \mathrm{T}_{40 \mathrm{~h}}$ & $F \hat{V} C=F \bar{V} C=10,996$ & - \\
\hline $\mathrm{D} 2 \times \mathrm{T}_{40 \mathrm{~h}}$ & $F \hat{V} C=F \bar{V} C=4,978$ & - \\
\hline $\mathrm{D} 3 \times \mathrm{T}_{40 \mathrm{~h}}$ & $F \hat{V} C=F \bar{V} C=3,632$ & - \\
\hline $\mathrm{D} 1 \times \mathrm{T}_{60 \mathrm{~h}}$ & $F \hat{V C}=19,358-0,0578^{*} P$ & 0,68 \\
\hline $\mathrm{D} 2 \times \mathrm{T}_{60 \mathrm{~h}}$ & $F \hat{V} C=F \bar{V} C=7,368$ & - \\
\hline $\mathrm{D} 3 \times \mathrm{T}_{60 \mathrm{~h}}$ & $\hat{F V C}=-11,363+3,038^{*} P^{0,5}-0,127^{*} P$ & 0,97 \\
\hline D1 x $T_{80 h}$ & $F \hat{V C}=21,458-0,0684^{\circ} P$ & 0,71 \\
\hline $\mathrm{D} 2 \times \mathrm{T}_{80 \mathrm{~h}}$ & $F \hat{V} C=32,859-4,306^{* *} P^{0,5}+0,158^{* *} P$ & 0,99 \\
\hline $\mathrm{D} 3 \times \mathrm{T}_{80 \mathrm{~h}}$ & $F \hat{V} C=F \bar{V} C=4,535$ & - \\
\hline
\end{tabular}


Table 5. Continuation.

\begin{tabular}{|c|c|c|}
\hline Combinations & Regression equations & $\mathbf{R}^{2}$ \\
\hline $\mathrm{D} 1 \times \mathrm{T}_{100 \mathrm{~h}}$ & $F \hat{V C}=22,503-0,0730^{\circ} P$ & 0,63 \\
\hline $\mathrm{D} 2 \times \mathrm{T}_{100 \mathrm{~h}}$ & $F \hat{V} C=F \bar{V} C=5,033$ & - \\
\hline $\mathrm{D} 3 \times \mathrm{T}_{100 \mathrm{~h}}$ & $F \hat{V} C=F \bar{V} C=4,730$ & - \\
\hline $\mathrm{D} 1 \times \mathrm{T}_{120 \mathrm{~h}}$ & $F \hat{V} C=F \bar{V} C=9,505$ & - \\
\hline $\mathrm{D} 2 \times \mathrm{T}_{120 \mathrm{~h}}$ & $F \hat{V} C=F \bar{V} C=5,705$ & - \\
\hline $\mathrm{D} 3 \times \mathrm{T}_{120 \mathrm{~h}}$ & $F \hat{V} C=F \bar{V} C=4,738$ & - \\
\hline $\mathrm{D} 1 \times \mathrm{T}_{140 \mathrm{~h}}$ & $F \hat{V} C=F \bar{V} C=9,935$ & - \\
\hline $\mathrm{D} 2 \times \mathrm{T}_{140 \mathrm{~h}}$ & $F \hat{V} C=F \bar{V} C=5,978$ & - \\
\hline $\mathrm{D} 3 \times \mathrm{T}_{140 \mathrm{~h}}$ & $F \hat{V} C=F \bar{V} C=4,925$ & - \\
\hline $\mathrm{D} 1 \times \mathrm{T}_{160 \mathrm{~h}}$ & $F \hat{V C}=45,392-0,176^{\circ} P$ & 0,65 \\
\hline $\mathrm{D} 2 \times \mathrm{T}_{160 \mathrm{~h}}$ & $F \hat{V} C=F \bar{V} C=5,629$ & - \\
\hline $\mathrm{D} 3 \times \mathrm{T}_{160 \mathrm{~h}}$ & $F \hat{V} C=8,487-0,0193^{\circ} P$ & 0,74 \\
\hline
\end{tabular}

$* *$, * and ${ }^{0}=$ significant at $1,0,5$ and $10 \%$ probability by the "t" test.

Yavuz et al. (2010) also found drip units with clogged emitters presenting changes to hydraulic performance indicators with increasing operating pressure.

Regarding the FVC as a function of operating times, Tables 3 and 5 show that the square root, linear and quadratic regression models fitted to $42 \%$ of the combinations, while the FVC as a function of operating pressures had $33 \%$ of square root and linear regression models fitting the combinations.

The operating pressure affected the DUC values for the combinations $\quad \mathrm{D}_{1 \times \mathrm{T}_{20}} \quad \mathrm{D} 2 \mathrm{xT}_{20 \mathrm{~h}}$,

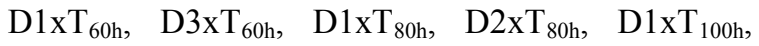
$\mathrm{D} \mathrm{xT}_{160 \mathrm{~h}}$ and $\mathrm{D} 3 \mathrm{xT}_{160 \mathrm{~h}}($ Table 6).

Table 6. Regression equations fitted to the average values of the DUC depending on the operating pressure (P; $\mathrm{kPa})$ of drip units for combinations of types of drippers and operating times (T; hours).

\begin{tabular}{|c|c|c|}
\hline Combinations & Regression equations & $\mathbf{R}^{2}$ \\
\hline $\mathrm{D} 1 \times \mathrm{T}_{0 \mathrm{~h}}$ & $D \hat{U} C=D \bar{U} C=95.161$ & - \\
\hline $\mathrm{D} 2 \times \mathrm{T}_{0 \mathrm{~h}}$ & $D \hat{U} C=D \bar{U} C=95,613$ & - \\
\hline $\mathrm{D} 3 \times \mathrm{T}_{0 \mathrm{~h}}$ & $D \hat{U} C=D \bar{U} C=96,601$ & - \\
\hline $\mathrm{D} 1 \times \mathrm{T}_{20 \mathrm{~h}}$ & $D \hat{U} C=74,929+0,170^{*} P-0,000375^{*} P^{2}$ & 0,99 \\
\hline $\mathrm{D} 2 \times \mathrm{T}_{20 \mathrm{~h}}$ & $D \hat{U} C=91,682+0,0159^{\circ} P$ & 0,72 \\
\hline $\mathrm{D} 3 \times \mathrm{T}_{20 \mathrm{~h}}$ & $D \hat{U} C=D \bar{U} C=95,815$ & - \\
\hline $\mathrm{D} 1 \times \mathrm{T}_{40 \mathrm{~h}}$ & $D \hat{U} C=D \bar{U} C=89,371$ & - \\
\hline $\mathrm{D} 2 \times \mathrm{T}_{40 \mathrm{~h}}$ & $D \hat{U} C=D \bar{U} C=94,683$ & - \\
\hline $\mathrm{D} 3 \times \mathrm{T}_{40 \mathrm{~h}}$ & $D \hat{U} C=\overline{D U} C=95,815$ & - \\
\hline D1 $\times \mathrm{T}_{60 \mathrm{~h}}$ & $D \hat{U} C=81,157+0,0513^{*} P$ & 0,89 \\
\hline $\mathrm{D} 2 \times \mathrm{T}_{60 \mathrm{~h}}$ & $D \hat{U} C=D \bar{U} C=91,922$ & - \\
\hline $\mathrm{D} 3 \times \mathrm{T}_{60 \mathrm{~h}}$ & $D \hat{U} C=98,557-0,0739^{*} P+0,000220^{*} P^{2}$ & 0,99 \\
\hline $\mathrm{D} 1 \times \mathrm{T}_{80 \mathrm{~h}}$ & $D \hat{U} C=75,565+0,0782^{\circ} P$ & 0,70 \\
\hline $\mathrm{D} 2 \times \mathrm{T}_{80 \mathrm{~h}}$ & $D \hat{U} C=79,686+0,170^{*} P-0,000423^{*} P^{2}$ & 0,99 \\
\hline $\mathrm{D} 3 \times \mathrm{T}_{80 \mathrm{~h}}$ & $D \hat{U} C=D \bar{U} C=95,351$ & - \\
\hline $\mathrm{D} 1 \times \mathrm{T}_{100 \mathrm{~h}}$ & $D \hat{U} C=77,160+0,0709^{\circ} P$ & 0,64 \\
\hline $\mathrm{D} 2 \times \mathrm{T}_{100 \mathrm{~h}}$ & $D \hat{U} C=D \bar{U} C=94,418$ & - \\
\hline D3 $\times T_{100 h}$ & $D \hat{U} C=D \bar{U} C=95,187$ & - \\
\hline $\mathrm{D} 1 \mathrm{x} \mathrm{T}_{120 \mathrm{~h}}$ & $D \hat{U} C=D \bar{U} C=89,132$ & - \\
\hline $\mathrm{D} 2 \times \mathrm{T}_{120 \mathrm{~h}}$ & $D \hat{U} C=D \bar{U} C=93,104$ & - \\
\hline $\mathrm{D} 3 \times \mathrm{T}_{120 \mathrm{~h}}$ & $D \hat{U} C=D \bar{U} C=94,700$ & - \\
\hline
\end{tabular}


Table 6. Continuation.

\begin{tabular}{clc}
\hline Combinations & \multicolumn{1}{c}{ Regression equations } & $\mathbf{R}^{2}$ \\
\hline $\mathrm{D} 1 \times \mathrm{T}_{140 \mathrm{~h}}$ & $D \hat{U} C=D \bar{U} C=88,534$ & - \\
$\mathrm{D} 2 \times \mathrm{T}_{140 \mathrm{~h}}$ & $D \hat{U} C=D \bar{U} C=93,958$ & - \\
$\mathrm{D} 3 \times \mathrm{T}_{140 \mathrm{~h}}$ & $D \hat{U} C=D \bar{U} C=94,783$ & 0,64 \\
$\mathrm{D} 1 \times \mathrm{T}_{160 \mathrm{~h}}$ & $D \hat{U} C=46,793+0,208^{\circ} P$ & - \\
$\mathrm{D} 2 \times \mathrm{T}_{160 \mathrm{~h}}$ & $D \hat{U} C=D \bar{U} C=93,930$ & 0,73 \\
$\mathrm{D} 3 \times \mathrm{T}_{160 \mathrm{~h}}$ & $D \hat{U} C=90,967+0,0208^{\circ} P$ & \\
\hline
\end{tabular}

*and ${ }^{0}=$ significant at 5 and $10 \%$ probability by the " $t$ " test.

The quadratic regression model best fitted to the combinations $\mathrm{D}_{1 \times T_{20}}, \mathrm{D}_{3} \mathrm{xT}_{60 \mathrm{~h}}$ and $\mathrm{D} 2 \mathrm{xT}_{80 \mathrm{~h}}$. Applying the first derivative in this model, the maximum DUC values were $94.20 \%$ for operating pressure of $227 \mathrm{kPa}\left(\mathrm{D} 1 \mathrm{xT}_{20 \mathrm{~h}}\right)$ and $96.77 \%$ for operating pressure of $201 \mathrm{kPa}\left(\mathrm{D} 2 \mathrm{xT}_{80 \mathrm{~h}}\right)$; and the minimum DCU value was $92.35 \%$ for operating pressure of $168 \mathrm{kPa}\left(\mathrm{D}_{3} \mathrm{xT}_{60 \mathrm{H}}\right)$. The linear regression model best fitted to the combinations $\mathrm{D} 2 \mathrm{xT}_{20 \mathrm{~h}}$, $\mathrm{D}_{1 \times T_{60 h}}, \mathrm{D}_{1 \times T_{80 h}}, \mathrm{D}_{1 \times T_{100 h}}, \mathrm{D} 1 \mathrm{xT}_{160 \mathrm{~h}}$ and $\mathrm{D} 3 \mathrm{xT}_{160 \mathrm{~h}}$. The mean was the best representation for the other combinations, regarding the DUC as a function of operating pressures.

Regarding the DUC as a function of operation times, Tables 4 and 6 show that the linear and the square root regression models fitted to $34 \%$ of the combinations, while the DUC as a function of operating pressures had $33 \%$ of linear and quadratic regression models fitting the combinations.
Nowadays, there is no safe method for assessing the risk of clogging by using wastewater. In order to provide a quantitative orientation, Bucks, Nakayama and Gilbert (1979) and Capra and Scicolone (1998) classified the risk of clogging of drippers with nominal flow of up to $12 \mathrm{~L} \mathrm{~h}^{-1}$ using criteria related to quality of irrigation water. The water quality characteristics, reported by Bucks, Nakayama and Gilbert (1979), were suspended solids, dissolved solids, hydrogenionic potential, manganese, iron, hydrogen sulfide and bacterial population; Capra and Scicolone (1998) reported the same characteristics, adding the calcium and magnesium.

Table 7 shows the multiple linear regression models of the FVC as a function of physicochemical and biological characteristics that cause obstructions in drippers for the combinations of drippers types and operating pressures.

Table 7. Regression equations fitted to the average values of the FVC depending on the physicochemical and biological characteristics that cause obstructions in drippers for the combinations of drippers types and operating pressures.

\begin{tabular}{|c|c|c|}
\hline Combinations & Regression equations & $\mathbf{R}^{2}$ \\
\hline D1 x P1 & $F \hat{V C}=-144,342+4,343^{* *} M^{2+}+0,0525^{* *} D S+0,00642^{* *} T C+26,742^{* *} F e+31,051^{*} M n$ & 1,00 \\
\hline $\mathrm{D} 2 \mathrm{x}$ P1 & $F \hat{V} C=F \bar{V} C=6,809$ & - \\
\hline D3 x P1 & $F \hat{V} C=-28,281+0,0145^{* *} S D$ & 0,75 \\
\hline D1 x P2 & $F \hat{V} C=F \bar{V} C=5,757$ & - \\
\hline $\mathrm{D} 2 \mathrm{x}$ P2 & $F \hat{V} C=F \bar{V} C=4,516$ & - \\
\hline D3 x P2 & $F \hat{V} C=F \bar{V} C=4,114$ & - \\
\hline D1 x P3 & $F \hat{V} C=F \bar{V} C=6,779$ & - \\
\hline $\mathrm{D} 2 \times \mathrm{P} 3$ & $F \hat{V} C=F \bar{V} C=5,509$ & - \\
\hline D3 x P3 & $F \hat{V} C=F \bar{V} C=4,501$ & - \\
\hline D1 x P4 & $F \hat{V} C=F \bar{V} C=5,122$ & - \\
\hline $\mathrm{D} 2 \times \mathrm{P} 4$ & $F \hat{V} C=F \bar{V} C=4,682$ & - \\
\hline D3 x P4 & $F \hat{V} C=F \bar{V} C=3,502$ & - \\
\hline
\end{tabular}

$* *$ and $*=$ significant at 1 and $5 \%$ probability for the "t" test.

The characteristics $\mathrm{Mg}^{2+}$, DS, TC, Fe and Mn affected the FVC values of the combinations D1xP1 and $\mathrm{D} 3 \mathrm{xP} 1$, while there was no effect of the physicochemical and biological characteristics that cause obstructions on FVC values of other combinations, indicating a low risk of obstruction.

Batista et al. (2008) selected models of multiple linear regressions for three types of drippers operating with tertiary domestic wastewaters, and 
found no effect of Mn, Fe, DS and $\mathrm{pH}$ on the mean flow values for drip units with the emitters M1 $(1.7 \mathrm{~L}$ $\left.\mathrm{h}^{-1}\right)$ and M2 $\left(2.1 \mathrm{~L} \mathrm{~h}^{-1}\right)$, and no effect of Mn and Fe on mean flow values for drip units with the emitter M3 $\left(2.0 \mathrm{~L} \mathrm{~h}^{-1}\right)$.
Table 8 shows the multiple linear regression models of the DUC depending on the physicochemical and biological characteristics that cause obstructions.

Table 8. Regression equations fitted to the average values of the DUC depending on the physicochemical and biological characteristics that cause obstructions in drippers for the combinations of types of drippers and operating pressures.

\begin{tabular}{clc}
\hline Combinations & \multicolumn{1}{c}{ Regression equations } & $\mathbf{R}^{2}$ \\
\hline D1 x P1 & $D \hat{U C}=237,820-5,715^{* *} M^{2+}-0,0565^{* *} D S-0,0160^{*} T C$ & 0,97 \\
D2 x P1 & $D \hat{U} C=D \bar{U} C=91,987$ & - \\
D3 x P1 & $D \hat{U} C=135,523-0,0179^{* *} D S$ & - \\
D1 x P2 & $D \hat{U} C=D \bar{U} C=93,671$ \\
D2 x P2 & $D \hat{U} C=D \bar{U} C=95,034$ & - \\
D3 x P2 & $D \hat{U} C=D \bar{U} C=95,694$ & - \\
D1 x P3 & $D \hat{U} C=D \bar{U} C=91,873$ & - \\
D2 x P3 & $D \hat{U} C=D \bar{U} C=94,124$ & - \\
D3 x P3 & $D \hat{U} C=D \bar{U} C=95,249$ & - \\
D1 x P4 & $D \hat{U} C=D \bar{U} C=94,294$ & - \\
D2 x P4 & $D \hat{U} C=D \bar{U} C=94,881$ & - \\
D3 x P4 & $D \hat{U} C=D \bar{U} C=96,310$ &
\end{tabular}

** and $*=$ significant at 1 and $5 \%$ probability for the "t" test.

The characteristics $\mathrm{Mg}^{2+}, \mathrm{DS}, \mathrm{TC}$ and $\mathrm{pH}$ affected the DUC values of the combinations D1xP1 and $\mathrm{D} 3 \times \mathrm{P} 1$, while there was no effect of physical, chemical and biological characteristics on the DUC values for the other combinations. Moreover, Dehghanisanij et al. (2005) found a linear effect of $\mathrm{pH}$, electrical conductivity, algae and zooplankton population on the dripper flow, operating with treated domestic wastewater.

\section{CONCLUSIONS}

The regression models that fitted to the FVC and DUC as a function of operating time were square root, linear and quadratic, with $17 \%, 17 \%$ and $8 \%$, and $17 \%, 17 \%$ and $0 \%$, respectively.

The regression models that fitted to the FVC and DUC as a function of operating pressures were square root, linear and quadratic, with $11 \%, 22 \%$ and $0 \%$ and the $0 \%, 22 \%$ and $11 \%$, respectively.

Multiple linear regressions showed that the dissolved solids content is the main wastewater characteristic that interfere in the FVC and DUC values of the drip units D1 (1.65 L h-1) and D3 (4.00 $\mathrm{L} \mathrm{h}-1)$, operating at work pressure of $70 \mathrm{kPa}(\mathrm{P} 1)$.

\section{REFERENCES}

ABNT - Associação Brasileira de Normas Técnicas. Equipamentos de irrigação agrícola - Emissores e tubos emissores - Especificações e métodos de ensaio. ABNT NBR ISO 9261. São Paulo: ABNT, 2006. 17 p.

ALVARES, C. A. et al. Köppen's climate classification map for Brazil. Meteorologische Zeitschrift, Stuttgart, v. 22, n. 6, p. 711-728, 2013.

BATISTA, R. O. et al. Modelos empíricos da irrigação localizada com esgoto sanitário tratado. Engenharia na Agricultura, Viçosa, v. 16, n. 3, p. 369-377, 2008.

BATISTA, R. O. et al. Efeito das características do esgoto doméstico na uniformidade de aplicação de sistemas de irrigação por gotejamento. Revista Caatinga, Mossoró, v. 24, n. 4, p. 137-144, 2011.

BATISTA, R. O. et al. Evaluación del desempeño hidraulico de tres goteros aplicando agua residual de porcicultura. Dyna, Medellin, v. 79, n. 173, p. 103108, 2012.

BATISTA, R. O. et al. Obstrução e uniformidade de aplicação em sistemas de irrigação por gotejamento aplicando-se efluente da suinocultura. Revista Brasileira de Engenharia Agrícola e Ambiental, Campina Grande, v. 17, n. 7, p. 698-705, 2013. 
BATISTA, R. O. et al. Gotejadores aplicando proporções de tempo de irrigação com efluente da suinocultura e água de abastecimento. Bioscience Journal, Uberlândia, v. 30, n .6, p. 1746-1756, 2014.

BUCKS, D. A.; NAKAYAMA, F. S.; GILBERT, R. G. Trickle irrigation water quality and preventive maintenance. Agricultural Water Management, Amsterdam, v. 2, n. 2, p. 149-162, 1979.

CAPRA, A.; SCICOLONE, B. Water quality and distribution uniformity in drip/trickle irrigation systems. Journal of Agricultural Engineering Research, London, v. 70, n. 4, p. 355-365, 1998.

CONAB. Companhia nacional de abastecimento. Conjuntura mensal: castanha de caju novembro de 2015. Brasília, DF: MAPA, 2015. 5 p.

DAZHUANG, Y. et al. Biofilm structure and its influence on clogging in drip irrigation emitters distributing reclaimed wastewater. Journal of Environmental Sciences, v.21, n.6, p.834-841, 2009.

DEHGHANISANIJ, $\mathrm{H}$. et al. The effect of chlorine on emitter clogging induced by algae and protozoa and the performance of drip irrigation. Transaction of the ASAE, St. Joseph, v. 48, n. 2, p. 519-527, 2005.

FERNANDES, R. K. A. et al. Vazão de gotejadores aplicando água residuária da castanha de caju. Irriga, Botucatu, v. 19, n. 4, p. 585-597, 2014.

LOPES, M. S. S. et al. Remoção de macronutrientes de efluente da indústria de castanha de caju por uso de reator aeróbio em batelada com inóculo fúngico. Engenharia Sanitária e Ambiental, Rio de Janeiro, v. 16, n. 1, p. 17-26, 2011

MESQUITA, F. O. et al. Uniformidade de aplicação de percolado de aterro sanitário diluído em unidades de irrigação por gotejamento. Agropecuária Científica no Semiárido, Patos, v. 11, n 1, p. 145 $156,2015$.

OLIVER, M. M. H.; HEWA, G. A.; PEZZANITI, D. Bio-fouling of subsurface type drip emitters applying reclaimed water under medium soil thermal variation. Agricultural Water Management, Amsterdam, v. 133, n. 1, p. 12-23, 2014.

PUIG-BARGUÉS, J. et al. Effect of flushing frequency on emitter clogging in microirrigation with effluents. Agricultural Water Management, Amsterdam, v. 97, n. 6, p. 883-891, 2010.

RICE, E. W.; BAIRD, R. B.; CLESCERI, A. D. Standard methods for the examination of water and wastewater. 22.ed. Washington: APHA, AWWA, WPCR, 2012. 1496 p.

ROWAN, M.; MANCL, K. M.; TUOVINEN, O. H. Evaluation of drip irrigation emitters distributing primary and secondary wastewater effluents. Irrigation \& Drainage Systems Engineering, New York, v. 2, n. 3, p. 2-7, 2013.

SAEG. Sistema para análises estatísticas versão 9.1. Viçosa: Fundação Arthur Bernardes, UFV, 2007. Disponível em: http://www.ufv.br/saeg/ Acesso em: 02 de jan. 2016.

SOUZA FILHO, H. M. et al. Barreiras às novas formas de coordenação no agrossistema do caju na região Nordeste, Brasil. Gestão \& Produção, São Carlos, v. 17, n. 2, p. 229-244, 2010.

SOUZA, C. F. et al. Eficiência de estação de tratamento de esgoto doméstico visando reuso Agrícola. Revista Ambiente \& Água, Taubaté, v. 10 , n. 3, p. 587-597, 2015

YAN, D. et al. Biofilm accumulation and structure in the flow path of drip emitters using reclaimed wastewater. Transactions of the ASABE, St. Joseph, v. 53, n. 3, p. 751-758, 2010.

YAVUZ, M. Y. et al. Emitter clogging and effects on drip irrigation systems performances. African Journal of Agricultural Research, Nairobi, v. 5, n. 7, p. 532-538, 2010 